\title{
NET ZERO-ENERGY HOME DESIGN STRATEGIES LEARNED FROM CANADIAN EXPERIENCE
}

\section{Masa Noguchi}

\begin{abstract}
In response to the growing demand for zero-energy housing, today's home needs not only to be energy-efficient, but also to provide part of its own energy requirements. The energy efficiency may be improved by applying high thermal performance building envelope and passive energy and environmental systems to housing. Micro-power can be generated through the use of renewable energy technologies. This paper is aimed at providing a comprehensive guideline on the design techniques and approaches to the delivery of net zero-energy healthy housing in view of the ÉcoTerra house, which won the Canadian federal government's EQuilibrium sustainable housing competition. The house was built in Eastman in the province of Quebec and it is currently open to the general public in order to sharpen the consumers' awareness of commercially available net zero-energy healthy housing today.
\end{abstract}

\section{Keywords:}

\section{INTRODUCTION}

The 'EQuilibrium' is Canada's official brand of the Net Zero Energy Healthy Housing Initiative, which was led by the Canada Mortgage and Housing Corporation (CMHC). It was aimed at bringing private and public sectors together to develop homes that encompass: climate- and site-specific design; energy- and resource-efficient construction; passive solar heating and cooling; natural day-lighting; integrated renewable energy systems; energy-efficient appliances and lighting; water conservation and re-use; land and natural habitat conservation; and sustainable community design and green infrastructure practices (CMHC 2007a). In short, the overall goals of Canada's EQuilibrium sustainable housing were:

- to develop a clear vision and approach to homebuilding;

- to build the capacity of the national housing and renewable energy industry sectors to create high product quality across the country over the long term;

- to achieve market acceptance of low-impact healthy houses and sustainable communities; and

- to enhance the domestic and global leadership in sustainable residential community design and development.

As a result, a total of 72 homebuilding teams submitted applications as of July, 2006. On 13th
February, 2007, the Honourable Monte Solberg, Minister of Human Resources and Social Development, and Minister responsible for $\mathrm{CMHC}$, and Jacques Gourde, Parliamentary Secretary to the Honourable Gary Lunn, Minister of Natural Resources, made the public announcement at CMHC's National Office and selected the twelve teams from the entries as winners of the EQuilibrium sustainable housing competition.

The ÉcoTerra house was one of the winning projects, built by Alovette Homes, the project lead and modular housing manufacturer. It was planned to demonstrate how far the low-energy healthy housing techniques and technologies can be implemented within marketable prices (Solar Buildings Research Network 2007). On 9th November, 2007, the grand opening of the ÉcoTerra house was held at the construction site where the Honourable Christian Paradis, Secretary of State, made the inaugural address and congratulated Alovette Homes on the successful construction of Canada's first EQuilibrium net zero-energy healthy house. The project was completed through a 'design charrette' process which is increasingly used as a planning tool to bring together relevant stakeholders for the design decisions (CMHC 2002). In fact, this project was carried out by a number of housing experts with multidisciplinary background. The architectural design of this house was developed by the author of this paper in collaboration with Alovette Homes' technical design team. The house was further engineered by $\operatorname{Dr}$ Andreas 


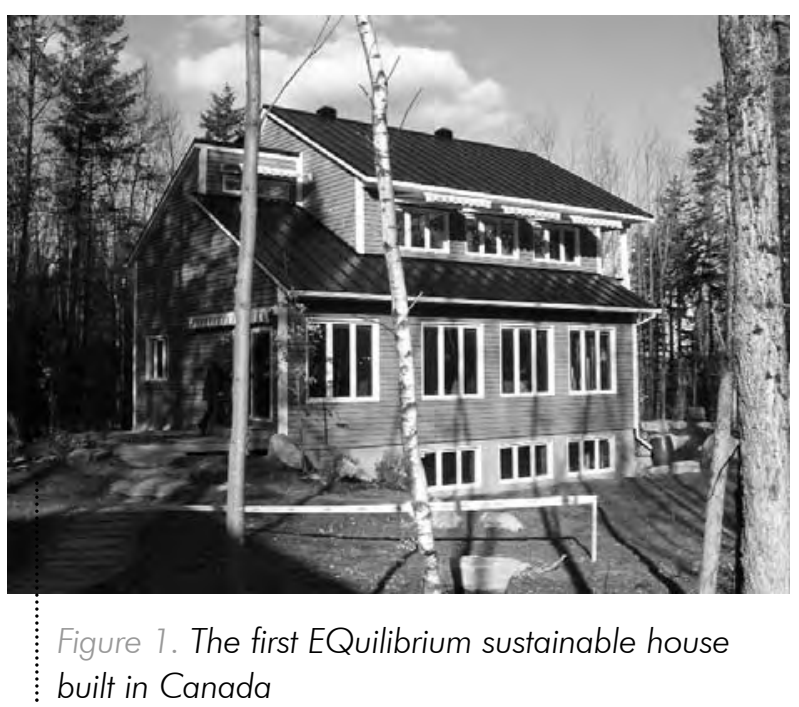

Athienitis, Concordia University, Dr Yves Poissant, Natural Resources Canada, and Claude Agouri, Airtechni Inc.

The ÉcoTerra house was an attempt to use a simple formula of adding readily-available renewable energy technologies to proven energy-efficient construction techniques in order to achieve Canada's energy efficient guide, or 'EnerGuide', for house rating in excess of 98 points. To achieve the project objectives, the team introduced a number of low-energy healthy housing techniques and technologies. The following sections provide technical information on the design features as to the health, resources, affordability and environmental aspects.

\section{TECHNICAL FEATURES}

The ÉcoTerra house is a single detached home built on a 1.1 hectare rural lot of a new residential development in Eastman in the province of Quebec. The floor area of this house is $141 \mathrm{~m} 2$ and 2 bedrooms are located on the first floor and semiprivate spaces, such as a kitchen, dining room, living room, and sunspace family room, are on the ground floor. A semi-basement is also introduced to this project designed and it serves as a multifunctional space and machine room. Accordingly, the total heated floor area of the house is estimated at $234 \mathrm{~m} 3$ including the basement whilst the heated volume is at $671 \mathrm{~m} 3$. The house was constructed by making use of Alovette Homes' pre-engineered modular housing system that helped eliminate or reduce on-site construction nuisances, such as bad weather, theft and vandalism. A closed garage is located on the north side of the house being attached to the façade; thus, it somewhat functions

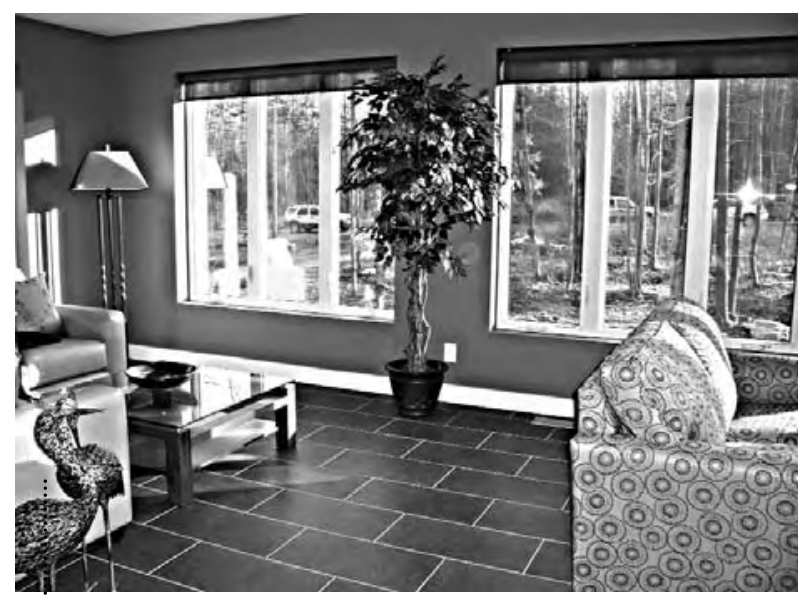

Figure 2. Concrete thermal floor mass covered with ceramic tiles

as an air buffer space that reduces the fabric heat loss. The south wall is fitted with generous southglazing (Fig 1). The window area of the south, west, east and north walls were estimated at $20.90 \mathrm{~m} 2$, $5.20 \mathrm{~m} 2,6.67 \mathrm{~m} 2$ and $0.65 \mathrm{~m} 2$, respectively. The south-glazing to floor ratio is $9.1 \%$.

The glazing areas allocated to the exterior walls of this house were designed to ensure the comfortable level of natural day-lighting and reduce the total amount of electricity required for artificial lighting. The daylight distribution of the house's ground floor was calculated in foot-candles ranging from 60 to 821 lux at noon on 21 st December. The availability of day-lighting exposure is of importance in the occupant's health and comfort. Thus, the technical features of these design aspects will be further described below.

\section{OCCUPANTS' HEALTH AND COMFORT}

One of the key healthy housing design features applied to the EcoTerra house is the thermal comfort maintained by the application of high thermal insulation materials (e.g. U-value of nearly $0.1 \mathrm{~W} / \mathrm{m} 2 \mathrm{~K}$ in external walls) and the air-tight construction. These features are further combined with the continuous, balanced mechanical ventilation. In this house, the air-tightness is maintained at lair change per hour (or $1 \mathrm{ACH}$ ) at $50 \mathrm{~Pa}$. The house is equipped with a balanced heat recovery ventilator (HRV) that has the capacity to recover up to $76 \%$ of heat lost through ventilation. This combination isolates the home from outdoor pollutants whilst ensuring that indoor pollutants are continuously exhausted. The mechanical ventilation also reduces 
airborne particulates and improves the indoor air quality that affects the occupants' health. Furthermore, the use of carpets was avoided particularly for the flooring of the lower levels. Instead of carpeting, the concrete floor mass was laid covered with ceramic tiles that can be cleaned and maintained easily after occupancy (Fig 2).

With due consideration of the day-lighting exposure (or solar gain potential) sufficient thermal mass was added to the ground and basement floors and walls of the house in order to provide the occupants with thermal comfort without depending solely on the mechanical heat load. The average daily isolation was estimated at $3.5 \mathrm{kWh} / \mathrm{m} 2$ in a horizontal position and $3.0 \mathrm{kWh} / \mathrm{m} 2$ in a vertical position. On the other hand, the overheating caused by strong sunlight during the cooling seasons was alleviated by the placement of sun-shading overhangs and motorised blinds (Figs 1\&2). Furthermore, the house was built to maximise the benefits of the rural setting and encompasses a number of broadleaf trees that comfortably shade a part of the dwelling unit during the summer and protect the house from cold winter winds that accelerate the fabric heat loss.

It can be assumed that heating the space has a tremendous impact on energy use in a house during the Canadian severe winter. However, it is inevitable in maintaining occupants' thermal comfort and health. At the construction site, the average ambient temperatures were measured at $-10.4^{\circ} \mathrm{C}$ in January, $4.6^{\circ} \mathrm{C}$ in April, $19.4^{\circ} \mathrm{C}$ in July and $7.1^{\circ} \mathrm{C}$ in October. Accordingly, the project's engineering team set the design temperatures of $-28^{\circ} \mathrm{C}$ in January and $29^{\circ} \mathrm{C}$ in July. The following section unveils the energy consumption profile of the ÉcoTerra house that was designed to achieve the net zero-energy target.

\section{ENERGY USE AND RENEWABLE TECHNOLOGIES}

The energy use in the ÉcoTerra house was analysed by making use of HOT2000 simulation software developed by Natural Resources Canada. In a house built in cold climates, the main energy use is often derived from the space heating in the winter. Furthermore, the energy consumption extends to regular water heating, as well as other domestic electric appliances, such as lighting fixtures and white goods. The annual space heating load of the ÉcoTerra house was originally estimated at $-90$
$21,795 \mathrm{kWh}$ without the contributions of passive solar techniques and active renewable energy technologies. With consideration of the house's achievable passive solar gains of $9,592 \mathrm{kWh} / \mathrm{yr}$ and potential internal gains of $3,491 \mathrm{kWh} / \mathrm{yr}$, the estimated annual energy requirement for space heating was reduced to $8,712 \mathrm{kWh}$. However, this figure still excludes the additional thermal effect of a solar photovoltaic (PV) power generating system, geothermal heat pump and thermal floor and wall mass that had been introduced to this house. As for the domestic hot water (DHW) tank that is covered with a blanket tank insulation, the annual energy consumption was approximated at 3,353kWh for a hot water load of $150 \mathrm{~L} /$ day at $55^{\circ} \mathrm{C}$. The annual electrical load required for interior lighting, appliances and exterior use electrical equipment (e.g. exterior lighting and dryer) was estimated at $3,975 \mathrm{kWh}$ and the load for mechanical ventilation was at $617 \mathrm{~kW} / \mathrm{h}$. Thus, the annual energy requirement of the house before the application of renewable energy technologies was reassessed at approximately $16,656 \mathrm{kWh}$.

However, this amount is still far from the zero-energy target. The following section reveals the further effect of the building-integrated photovoltaics (BIPV) integrated with a thermal heat recovery system and a geothermal heat pump for supplying hot water. The application of these technologies strongly characterise this residential project and the design features will be described in the following sections.

\section{BIPV/THERMAL SYSTEM}

Building integrated photovoltaic thermal (BIPV/T) systems have a great advantage compared with stand-alone PV arrays or solar thermal collectors because they generate both thermal and electrical energy simultaneously (Chen et al. 2007). Therefore, a $3 \mathrm{~kW}$ BIPV/T based on a system concept developed at Concordia University was installed in the ÉcoTerra house, having the capacity to produce approximately $12 \mathrm{~kW}$ of heat at $14 \mathrm{~m} 3 / \mathrm{min}$ of air flow according to the engineering team's previous experiment (Liao et al. 2007). The $\mathrm{PV}$ array of the BIPV/T system is comprised of 22 amorphous silicon $136 \mathrm{~W}$ laminates placed on the $55 \mathrm{~m} 2(5.8 \mathrm{~m} \times 9.5 \mathrm{~m})$ south-facing metal rooftop (Fig 1). The potential annual electricity production was estimated initially at approximately $3,420 \mathrm{kWh}$ when the roof faces is sloped at $30.3^{\circ}$. The analy- 


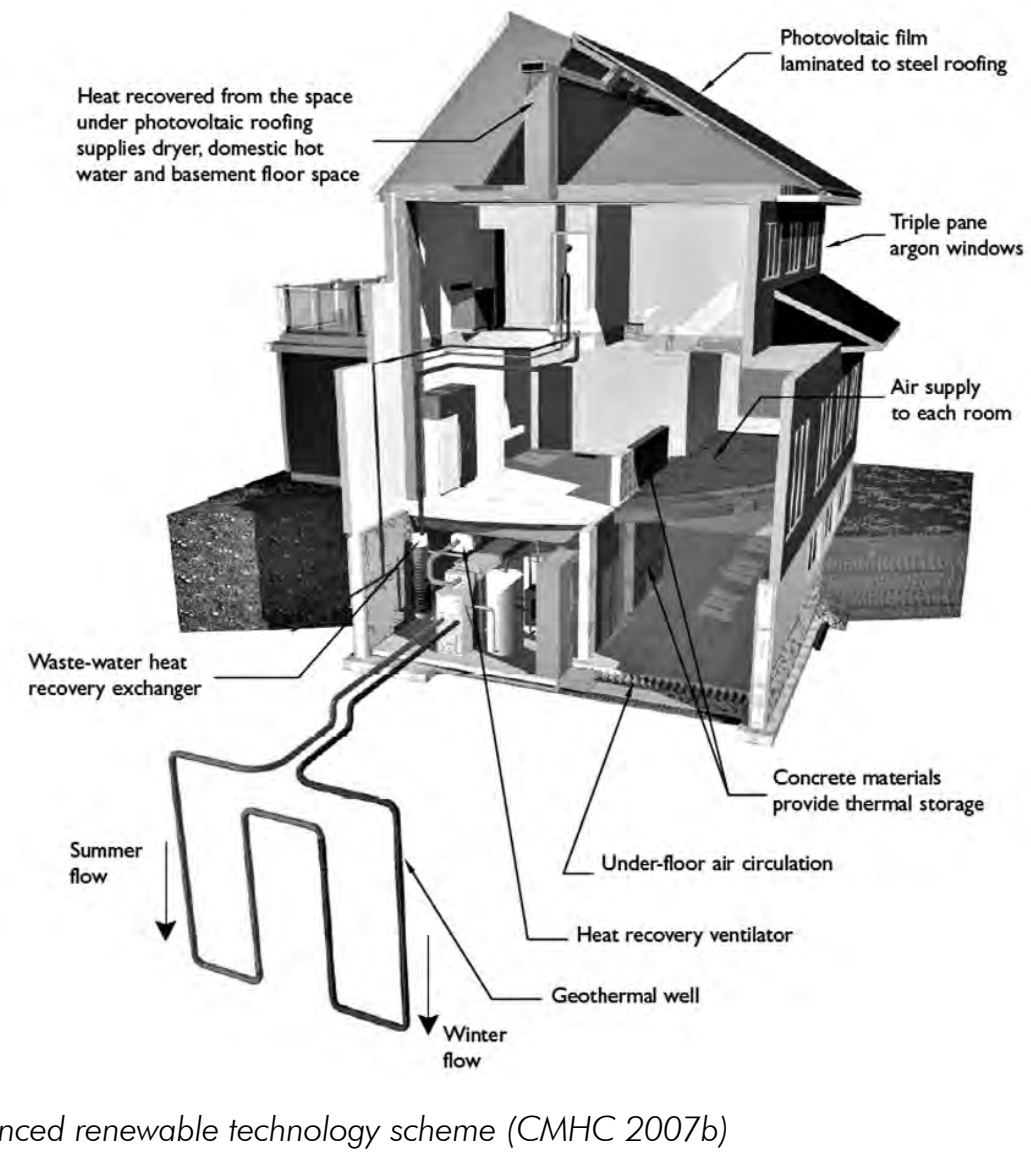

Figure 3. Advanced renewable technology scheme (CMHC 2007b)

sis was conducted by making use of RETScreen International simulation software developed by Natural Resources Canada. The BIPV/T system is an on-grid application accompanied with an inverter for the AC/DC conversion and it allows for redirection of locally generated electricity surpluses to the grid through a net metering programme.

Fresh air is drawn from inlets located in the roof soffits since as a duct space the cavity was created under the PV panels by the placement of vertical $25 \mathrm{~mm} \times 50 \mathrm{~mm}$ (nominal size) furring strips. They are further covered with horizontal wooden strips that hold the metal roof sheets. The amorphous PV panels are thin rolls so that they can directly be attached to the metal roof sheets before the onsite assembly. The air under the PV panels is heated by solar radiation, drawn into the lower portion of the house from the roof ridge ducted (Fig 3).

In Canada, the inlet air in the cavity of the south-facing wall or roof tends to be approximately $5-10^{\circ} \mathrm{C}$ warmer than the ambient temperature when wind cooling effects are ignored. The flow velocity of the air under PV panels varies from a minimum of $0.5 \mathrm{~m} / \mathrm{s}$ to a maximum of $1 \mathrm{~m} / \mathrm{s}$ and the outlet air temperature ranges from $15^{\circ} \mathrm{C}$ to $30^{\circ} \mathrm{C}$ higher than the ambient air temperature (Liao et al. 2007). In the ÉcoTerra house, the air heated by the
$\mathrm{BIPV} / \mathrm{T}$ system is used for drying clothes when the outlet air temperature is higher than $15^{\circ} \mathrm{C}$. This application drastically reduces or eliminates the energy required for the operation of an electric dryer, which consumes electricity at nearly $900 \mathrm{kWh} / \mathrm{yr}$. Furthermore, the heated air is used to supplement the energy required for preheating water through an air-to-water heat exchanger installed in the house when the outlet air temperature is higher than $6^{\circ} \mathrm{C}$. In addition, the heated air from the BIPV/T system is also used for thermal mass heating. The basement floor on the south side is equipped with thermal mass in which metal form decking is laid before concrete is poured (Fig 3). Thus, the cavity in the concrete floor mass allows for the flow of air heated by the BIPV/T system and the concrete slab in turn stores the heat during the daytime and releases it at night. However, it works only when the outlet heated air temperature is at least $2{ }^{\circ} \mathrm{C}$ higher than the thermal mass temperature.

The BIPV/T system introduced to the ÉcoTerra house contributes to the drastic reduction of energy consumption for heating the space and water in addition to the alleviation or elimination of an electric clothes dryer use. From November to March, the thermal mass in the basement is likely heated by the warm air from the BIPV/T system with an aver- 
age daily recovered thermal energy of $20-50 \mathrm{kWh}$ totalling approximately $3,800 \mathrm{kWh}$ of the space energy load in the heating season. For the other 7 months, the warm air is used for heating water when it is not applied to drying clothes. Thus, the annual heating energy consumption for the heat pump can be reduced by the operation of the $\mathrm{BIPV} / \mathrm{T}$ system and the saving was estimated at $1,100 \mathrm{kWh}$.

\section{GEOTHERMAL HEAT PUMP}

The ÉcoTerra house is heated or cooled by twostage geothermal heat pump (GHP) with environmentally friendly refrigerant. The compressor was located in a machine room. In addition to space heating through a ducted forced air system, the heat pump assists water heating with a desuperheater. It is expected to reduce the energy consumption related to heating by approximately $700 \mathrm{kWh} / \mathrm{yr}$. The system's lifespan was considered to be over 20 years. All mechanical equipment including the geothermal heat pump, BIPV/T fan, electricity distribution panel, heat recovery system and heat exchanger was concentrated in the basement mechanical room enclosed by concrete thermal mass. The house was also designed to use the heat released from these machines to supplement space heating by letting the warm air circulate through the open staircase driven by stack effect.

With due consideration of the utilisation of the above-mentioned advanced renewable energy technologies combined with passive solar techniques applied to the ÉcoTerra house, the annual space energy consumption would become as low as $1,130 \mathrm{kWh}$. The electricity used for DHW was reduced from $3,353 \mathrm{kWh}$ to $553 \mathrm{kWh}$ as a result the contributions of the heat pump desuperheater, BIPV/Thermal system and $21 \%$ efficient drain-water heat recovery unit (DWHR). As for the energy consumption of indoor lighting, appliances and exterior use electrical equipment, it was decreased from $3,975 \mathrm{kWh}$ to $3,275 \mathrm{kWh}$ with the reduced energy load for an electric dryer. Subtracting the PV electricity generation of $3,420 \mathrm{kWh}$ from the sum of these figures, the annual energy consumption of the ÉcoTerra house can be re-estimated at 2,155kWh.

To achieve the net zero-energy target, the balance between the house's energy consumption and the generation patterns over the period of a year needs to be taken into account. The following section describes the housing affordability aspect of $-92$ the ÉcoTerra house with due consideration of the net metering arrangement.

\section{HOUSING AFFORDABILITY}

Housing affordability may be assumed to be one of the key aspects that affect the mass marketing of any innovative housing and it concerns both the initial selling price and the operating cost. A house may need to be designed in a cost-effective way to reduce the energy and material consumptions to meet sustainability agenda. Friedman (2001) systematises the production approaches to affordable sustainable homes and his systematic design techniques may be worthy to consider before expensive renewable energy technologies are introduced to housing in order to reduce the initial cost (Noguchi 2004).

In the ÉcoTerra house project, the local power company, Hydro-Québec, was in the position to allow this residential development to demonstrate the net metering arrangement that enables the occupants to use their own power generation to offset their electricity consumption over a billing period. Accordingly, this housing project benefits from this arrangement and it is assumed to demonstrate the net zero energy consumption at the end of a year after occupancy. Basically, the users receive retail prices for the excess electricity that is generated by the renewable energy sources installed in the house (Fig 4). Thus, the ÉcoTerra house can be considered as an affordable green home in the light of the net zero energy consumption that relates to the utility cost. However, this makes sense only when the initial cost is less of a consideration.

The total construction cost of the house was estimated at $\$ 457,379$ (CAD). 17\% of the total cost was derived from the land. The build cost that includes the foundation, modular sections, on-site assembly, electrical and plumbing hook-ups and finishing work involved the half of the cost or $54 \%$. The renewable technologies such as BIPV/T and geothermal heat pump systems were estimated at $14 \%$ of the cost. The remainder or $15 \%$ of the cost was allocated to the builder's overhead and profit. Over the last few years, Canada's new housing price has been hiked up drastically and the average price of housing increased 53\% (excluding the land value) in 2007 when compared to that in 1997 (Royal Bank of Canada 2008). In 2007, the average price of 2 -storey detached housing was 
Energy Consumption by End Use

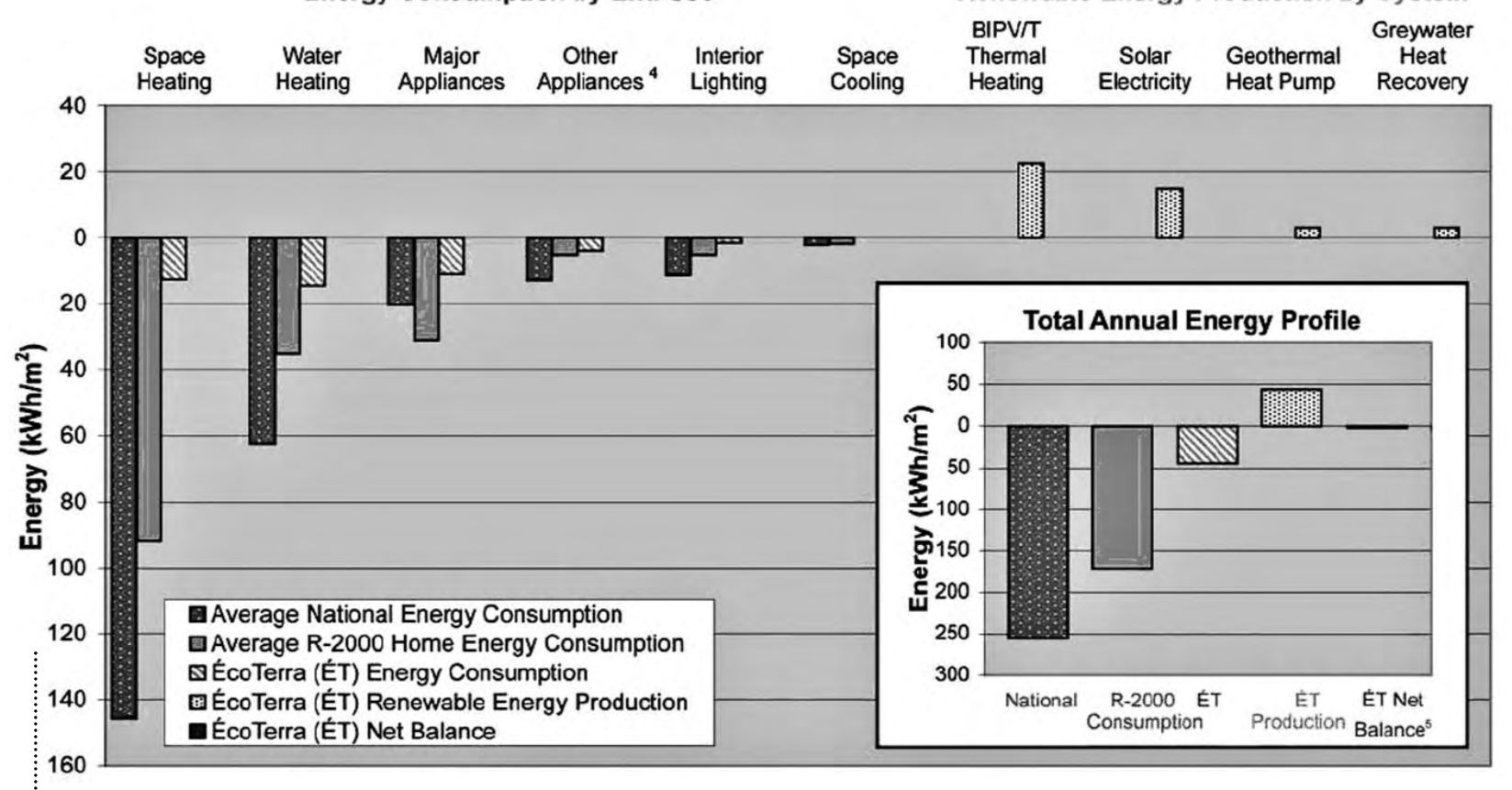

Figure 4. Annual energy consumption and production profiles of the ÉcoTerra house and other typical homes in Canada (CMHC 2007b)

assessed at $\$ 345,575$. This suggests that the selling price of the ÉcoTerra house built in 2007 is about $32 \%$ more expensive than the national average in the Canadian market and may only appeal to the wealthy niche.

One of the key factors that helped increase the construction cost of the ÉcoTerra house can be considered to be the installation of renewable energy technologies; however, these advanced technologies are almost inevitable in the production of zero-energy housing today. This housing project also introduced an expansion space for PV and/or solar thermal panels. The lower south-facing roof of the ÉcoTerra house will not be clad with any solar panels at the time of sales; however, the surface allows for the occupants' future installation. It is assumed that the house's energy demand may increase over time as the price of PV systems, for instance, degreases (Maycock 1997). Thus, the tendency may help boost buyers' affordability for the renewable energy technology that contributes considerably to reducing or eliminating the energy cost after occupancy, as identified previously.

In the ÉcoTerra house, the team also introduced a high thermal performance foam insulation material that is relatively new to Canadian homebuilders including the project's lead. The use of innovative materials unfamiliar to the builder might have a significant impact on increasing the produc- tion cost of the ÉcoTerra house. The development of a new housing prototype may hardly benefit from the economies of scale unless the prospective market for mass marketing is guaranteed. The selling price of the house may be reduced when the production efficiency accompanied with the mass sales increases. As part of the dissemination strategies for the sequential ÉcoTerra houses, the emerging notion of 'mass customisation' was taken into consideration. This attempt reflects the author's previous research on the 'mass custom design' approach to quality affordable homes (Noguchi and Friedman 2002; Noguchi and Hernández 2005). The studies indicate that the cost associated with a number of design meetings between the designerbuilder and the buyer can be reduced roughly by $30-60 \%$ when the design approach is applied to the delivery of sequential homes (Noguchi 2004).

\section{CONCLUSION}

Fundamentally, homes should be designed based on affordable housing design techniques to reduce the initial and future costs. Moreover, for the production of low-energy housing, the walls and roofs need to be equipped with high thermal performance insulation material that reduces the fabric heat loss. As well, air-tight construction approaches 
to reducing the ventilation heat loss should be incorporated into the building envelope. Passive solar techniques are inevitable in maximising the use of free clean sunlight for water- and spaceheating as well as day-lighting. The installation of active renewable energy technologies is effective in supplementing electricity required for the operation of a house after occupancy. In addition to these tangible design solutions that contribute to lowering energy consumption of a house, a net metering arrangement takes a crucial part in the delivery of net zero-energy housing.

To disseminate net zero-energy housing, the effects of the feed-in-tariff and time zone contract schemes that have successfully been implemented by some power companies around the globe may need to be examined. As well, housing design should incorporate strategies that aim to turn energy users in a house into the savers and further research on the users' behavioural patterns for energy saving may need to be conducted to identify the intangible design solutions for the eco-friendly healthy operation of housing.

\section{ACKNOWLEDGEMENTS}

Financial support for this design project was provided partially by CETC-Varennes, Natural Resources Canada. This paper reflects national and international efforts to accomplish the missions and objectives of the Solar Buildings Research Network that is led by Prof. Andreas Athienitis, Concordia University. The author would like to extend his sincere gratitude to all team members of the ÉcoTerra housing project and Dr Lisa Dignard-Bailey, CETCVarennes, for their constructive comments received in the course of this housing design and research project. Special thanks are also conveyed to $\mathrm{Mr}$ Bradley Berneche, Alovette Homes, for his project initiative and leadership that were necessary for the actualisation of Canada's first net zero-energy healthy home that has become commercially available today.

\section{REFERENCES}

CANADA MORTGAGE AND HOUSING CORPORATION (CMHC), 2002, Sustainable Community Planning and Development: Design Charrette Planning Guide, CMHC, Ottawa.

CHEN, Y., ATHIENITIS, A. K., GALAL, K. E., and POISSANT, Y., 2007, 'Design and Simulation for a Solar House with Building Integrated Photovoltaic-Thermal System and Thermal Storage,' ISES Solar World Congress, Beiiing, China, Vol. I, pp. 327-332.

CMHC, 2007a, EQuilibrium Healthy Housing for a Healthy Environment New Housing for a Changing World, CMHC, Ottawa.

CMHC, 2007b, EQuilibrium Healthy Housing for a Healthy Environment Project Profile: ÉcoTerraTM House-Eastman, Quebec, CMHC, Ottawa.

FRIEDMAN, A., 2001, The Grow Home, McGill-Queen's University Press, Montreal.

LIAO, L., ATHIENITIS, A.K., CANDANEDO, L., PARK, K.W., POISSANT, Y., and COLLINS, M., 2007, Numerical and Experimental Study of Heat Transfer in a BIPV-Thermal System,' Journal of Solar Energy Engineering, 129, pp. 423430.

MAYCOCK, P.D., 1997, 'Cost Reduction in PV Manufacturing: Impact on Grid-Connected and buildingIntegrated Markets,' Solar Energy Materials and Solar Cells, Vol. 47, No. 1, pp. 37-45.

NOGUCHI, M., and FRIEDMAN, A., 2002, 'Mass Custom Design System Model for the Delivery of Quality HomesLearning from Japan's Prefabricated Housing Industry, Proceedings of the International Council for Research and Innovation in Building and Construction W060-096 Syllabus Joint Conference: Measurement and Management of Architectural Value in Performance-Based Building. Hong Kong, pp. 229-243.

NOGUCHI, M., 2004, A Choice Model for Mass Customisation of Lower-cost and Higher-Performance Housing in Sustainable Development, Ph.D. Dissertation, McGill University, Montreal.

NOGUCHI, M., and HERNÁNDEZ, C., 2005, 'A 'Mass Custom Design' Approach to Upgrading Traditional Housing Development in Mexico,' Journal of Habitat International, Vol. 29, No. 2, pp. 325-336. 
SOLAR BUILDINGS RESEARCH NETWORK, 2007, 'CMHC's

EQuilibrium Housing Initiative a Venue for Demonstrating Network Technologies,' Solar Building Research Network

Newsletter, September, Vol. 1, No. 3, pp. 9-10.

ROYAL BANK OF CANADA, 2008, Economic Research

Housing Affordability, RBC, Toronto.

\section{Authors' Address}

Dr Masa Noguchi

MEARU

Mackintosh School of Architecture

The Glasgow School of Art

11 Dalhousie Street

Glasgow, G3 6RQ, UK

m.noguchi@gsa.ac.uk 